observations, using a specimen of glycuronolactone kindly given by Dr. E. L. Hirst, and two specimens of "30 per cent methylnornarcotine", one prepared by Rygh and the other prepared in this laboratory. Young guinea-pigs were fed upon a scurvy-producing basal diet, and given a daily supplement of methyl. nornarcotine, or of glycuronolactone, or of both together, in the amounts specified by Rygh. ${ }^{2}$ On the sixteenth day the animals were losing weight rapidly, so they were killed and examined for (a) hrmorrhage at the knee-joint, $(b)$ rib-beading, and (c) suprarenal staining with dilute silver nitrate solution after Moore and Ray. ${ }^{8}$ All those animals which had been receiving any of the supplements showed signs of marked or severe seurvy indistinguishable from the condition of the negative controls, while the positive control animals (which had received $10 \mathrm{gm}$. of cabbage daily) were free from scurvy. The lower jaws of all the guinea-pigs were removed for histological examination of the teeth, and full details of the experimental observations will be published elsewhere when this examination has been completed.

The Dunn Nutritional Laboratory,

University of Cambridge and

Medical Research Council,

Milton Road, Cambridge.

$$
\text { Dec. } 7 .
$$

${ }^{1}$ Rygh and Rygh, Z. physiol. Chem., 204, 114.

2 Rygh, Rygh and Laland, $Z$. physiol. Chem., 204, 105.

S Smith and Zilva, Chem. Ind., 51, 166.

- Grant, Smith and Zilva, Biochem. $J_{\text {., }}$ 26, 1628.

- Dalmer and Moll, $z$. physiol. Chem., 209, 211.

- Dann, Forsyth, Harris, Mills and Innes, Lancet, 2, 237 ; 1932.

?Rygh and Rygh, Z. physiol. Chem., 211, 275 .

- Moore and Ray, NATURE, 130, 997, Dec. 31, 1932.

\section{Union of Pycniospores and Haploid Hyphæ in Puccinia Helianthi Schw.}

THE discovery ${ }^{1}$ that, in a heterothallic rust like Puccinia graminis Pers., or $P$. helianthi Schw., the transfer of pycniospore-containing nectar from a monosporidial (haploid) pustule of one sex to a similar pustule of the opposite sex induces the development of æcia in the pustule receiving the nectar has stimulated interest in the process by which the diploidisation is effected.

In the examination of free-hand sections of monosporidial pustules of $P$. graminis and $P$. helianthi, I have observed that usually two types of hyphæ protrude through the ostiole of a pycnium: (1) the stiff tapering slightly-curved paraphyses, which have been frequently figured; and (2) flexuous hyphæ which show considerable variation in length, dia. meter, regularity of outline, and a few other features. In some of the pycnia-probably the older ones-of a pustule, these flexuous hyph may show rather profuse development ; in others, only a few of them, sometimes none, are discernible. They may be shorter, but usually they are as long or longer than the paraphyses, not infrequently two or three times as long. They may branch, but they rarely show septations. Some may be swollen at the tip. Occasionally a short spur or peg, of less diameter than a branch, juts out at a side or tip.

Several pycniospores in union with such hyphæ have been observed in sections of haploid pustules of $P$. helianthi in which the nectar had been previously intermixed, so that presumably both $(+)$ and $(-)$ pycniospores were present on the surface of each pustule and in close proximity to the protruding hyphæ.

Fig. I shows such a union. The pycniospore is empty; and the hypha has lost most of its cytoplasm. Presumably the nucleus of the pycniospore has passed through the connecting tube into the hyphs and proceeded down it, to associate itself in conjugate relationship with some nucleus of the mycelium.

With regard to the short spurs or pegs on these hyphæ, it is assumed that a hypha of one sex, in response to the presence in its immediate vicinity of a pycniospore of the opposite sex, sends out a short tube to establish contact with that pycniospore.

A nucleus in the act of passing from a pyeniospore into a hypha has not been seen, but empty pycnio. spores found connected by short tubes to these hypha furnish strong circumstantial evidence that nuclei migrate from pycniospores to these hyphæ by way of fusion tubes.

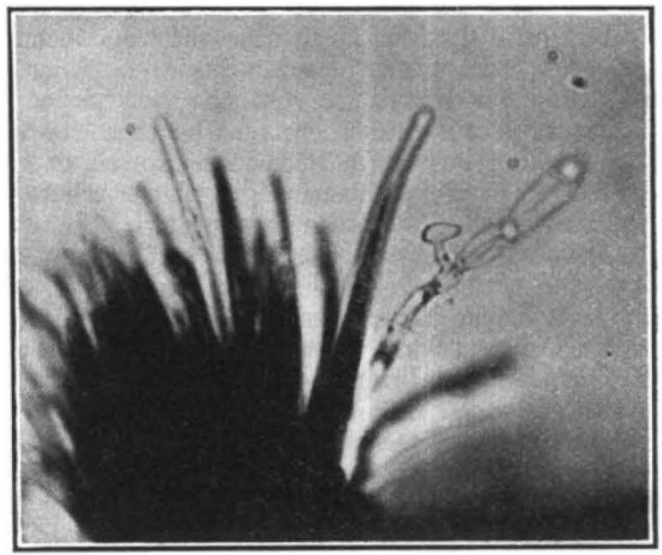

Frs. 1.-The union of a pycniospore and a flexuous hypha in a haploid pustule of $P$. helianthi. The pustule was fixed in formalin acetic alcohol $13 \frac{1}{2}$ hours after the intermixing of Brown.

Hyphæ which emerge through stomata and between epidermal cells were observed by Andrus ${ }^{2}$ in haploid pustules of Uromyces appendiculatus and $U$. vignce, and by Allen, ${ }^{3}$ in haploid pustules of Puccinia triticina. Andrus regards these hyphæ as the tips of functioning trichogynes. Allen designates them "receptive hyphæ". However, neither of these investigators found direct evidence of fusions between 'spermatia' (pyeniospores) and trichogynes or receptive hyphr, although both assume from their studies that direct fusions do occur.

There is little doubt that, in haploid pustules of $P$. helianthi (or of $P$. graminis), the function of the protruding hyphæ is to establish contact between mycelia of one sex and pycniospores of the opposite sex and thus to serve as an avenue by which the nuclei of the pyeniospores reach the internal mycelia of the pustules. The type of union so far observed simulates that of oidium and hypha in the Hymenomycetes.

\section{J. H. Craigre.}

Dominion Rust Research Laboratory, Winnipeg, Manitoba. Nov. 17

Craigie, J. H., NATCRE, 120, 765, Nov. 26, 1927.

Andrus, C. Frederic, $J$. Agr. Res., 42, 559-587; 1931

Allen, Ruth F., J. Agr. Res., 44, 733-754; 1932. 